grant system, the increased grant, he suggested, should be paid direct to the college and the balance recouped from one or more of the local education authorities concerned. Under such a scheme it would be possible to plan long-term developments-Dr. Venables hinted here at the quinquennial principleacademic freedom could be secured for the staff and residential hostels would be more readily forthcoming. Such major institutions would not be able to provide for all aspects of technological work, and closer links would be desirable with the industrial research associations, which have their own part to play. Nevertheless, he thought that, by increased full-time and sandwich courses, by post-advanced or postgraduate courses and by research in co-operation with industry and the research associations, and further development of management education and training, the fifteen major technical colleges he visualized could make a greatly enlarged and vital contribution to advanced technology in Great Britain.

Dr. Venables's suggestion to concentrate on twelve or fifteen major institutions was supported by $\mathrm{Mr}$. Wilson, and in the discussion Mr. D. J. Williams assured him of the whole-hearted support of the Association of Principals of Technical Institutions. Mr. Williams also advocated a separate major technical colleges committee. There was some general support, too, for the view that the present grants system is weighted in favour of the universities and the arts rather than the technical colleges and the sciences. In his address during the afternoon session on education and the administrative and financial structure of local government, Prof. S. E. Finer, University College of North Staffordshire, presented evidence that, in spite of the steady increase in educational expenditure, local authorities are still not spending nearly as much as they could and should on education; but his address did not bear very closely on the special issues raised by Dr. Venables. Prof. Finer was convinced that we need as strong a local government as can be achieved consistently with national standards, and that it is absolutely impracticable to centralize the administration of the schools. A recalculation of 1938 costs in terms of 1953 prices and school population shows that there has been virtually no increase in that part of the cost of each child's education which falls on local authorities. The real rate burden is very small and has become very much lower than before the War. The case for additional grant seems to be exaggerated, and he thought that local authorities should continue to bear the burden, subject to a reform of the education grant formula to make it more distributive, and based on a rating revaluation in 1956 with provision for a more elastic policy of exemptions and allowances in hard cases.

The sessions on January 6 were concerned with education in other countries, in which Prof. J. A. Lauwerys, University of London Institute of Education, dealt with the situation in the United States, and Dr. G. B. Jeffery, director of the University of London Institute of Education, with the position in the African Colonies. Prof. Lauwerys emphasized the diversity, the size and newness of the American system. There is urgent need, he said, for the development of educational practices which will foster the steadiness of character, power of critical thinking, independence of judgment and the vision that America's new role of leadership demands of her citizens. Of the comprehensive school, he suggested that the British would do well to study with care American experience and then try to avoid repeating the mistakes made by others : one cannot say that because comprehensive schools work in the United States they would work in Britain. On the whole, he thought that the American system is better geared than the British to the imperative requirements of an industrial and technological education, and this aspect also deserves close study. Prof. Lauwerys was also very impressed by the enormous strides which have been made during the past twenty years in developing the professional aspects of the study of education.

Dr. Jeffery's address outlined the rapid progress made by the newly created Gold Coast Government, and in the subsequent discussion Mr. A. L. Binns described the very different conditions in East Africa. Dr. Jeffery maintained that the new development plans of the African ministers to-day, which he believed are fundamentally right in the practical circumstances, in spite of foreseeable dangers, are possible only because of the efforts of missions and the Colonial Education Service over many generations. In East Africa, Mr. Binns thought that the only hope lies in a great reinforcement of the few teams of British technicians and teachers who are already raising moral and material standards in small areas, so that the effort may be sustained long enough for the development of character in African leaders when moral stamina has been undermined by the dissolution of their traditional culture. In this connexion, Mr. T. H. Baldwin urged that educationists should make it possible for British teachers to take short-term appointments in the Colonies without jeopardizing their prospects at home. On January 7, in a paper on the place of the three 'R's' in the curriculum, Miss M. V. Daniel, principal of Hereford County Training College, urged that language, whether in reading or writing, should be envisaged as the means of communicating ideas, and mathematics as an interpretation of the physical world.

\section{AGRICULTURAL CROPS: QUALITY VERSUS QUANTITY}

A MEETING of considerable significance to British agriculture was held at Cambridge during December 15 and 16 , when the National Institute of Agricultural Botany held its second Crop Conference with the theme of "Varieties in Relation to Crop Production". More than five hundred Fellows of the Institute, including farmers, seed merchants, maltsters, brewers, millers and agricultural scientists, attended to hear papers and discuss the topical problems posed by a quickly changing national and international position in relation to the production of primary agricultural products. The bulging wheat silos of North America and the threats of surpluses of coarse grain from the U.S.S.R. and other countries, coupled with a 'free market' for grain in Great Britain, acted as a stimulating, if sobering, brekground to the proceedings, and it was a matter of great interest to see how the conference quickly settled down to discuss the economics of quality versus quantity in the production of two of the three crops being consideredbarley, sugar beet and wheat.

Dr. H. Hunter introduced the subject of the barley crop, which occupied most of the first day, and 
immediately the conference was plunged into the intricacies of crop ecology, the physiology of development, the action of fertilizers, and the relationship between yield and malting quality. Very soon, also, the vital impact of plant breeding on crop production became apparent, and the conflict of interests between the farmer and the brewer, when considering the best varieties to grow, asserted itself. It appeared, however, that the newer hybrid varieties are helping to bridge the gap, and the farmer may not have to decide whether to grow for quality or quantity, because it is hoped these hybrids may combine both attributes.

This last point was emphasized by two of the three following papers on barley, in which Mr. C. S. Elliott described the behaviour of the new varieties and unnamed hybrids in the official N.I.A.B. trials, and Commander A. Cory-Wright put the maltsters' and brewers' points of view in considering varietal behaviour and the processors' requirements. Elliott's account traced the changes in barley varieties available in Britain since the advent of Spratt-Archer and Plumage-Archer, which are still generally the maltsters' and brewers' first choice, through the introduction of the Danish variety Abed Kenia, with its stronger straw, earlier ripening and potentially higher yielding capacity of poorer quality grain, to the greatly increased number of foreign varieties of similar type but often of no greater value. The problem has been to try to find a variety combining the desirable grain characters of the Archer barleys with the improved field characters of the Danish and Scandinavian varieties, and considerable progress has been made in this direction with the newest hybrids between varieties representing these two classes of barley. Thus the Danish variety Carlsberg and the English variety Proctor may be considered as real advances in combining higher yield with good molting quølity; while other English hybrids are due for release next year.

Cory.Wright's contribution emphasized the change in the varietal position, the dangers of increasing the number of varieties, and the impossibility of making an overall general analysis to cover individual brewer's requirements in spite of a widely accepted interpretation of what is good malting barley. It appeared, however, that growers' and processors' views on varieties were by no means irreconcilable, though a word of warning was given concerning certain new varieties like Herta and Rika with pretensions to being malting barleys but with greater suitability for stock feed. Considerable interest was shown in Dr. A. Eden's paper on the utilization of barley for feeding, and the place of this cereal in the animal's ration, in relation to the composition of the grain.

A different aspect of quality was discussed by Mr. S. T. Skelton, on the afternoon of the first day, when he dealt with the quality of seed stocks. Skelton described the two main aspects of this quality as the appearance-size, colour, and freedom from damage, disease and impurities-and the authenticity and purity of strain or variety. The use of better methods of handling seed with improved machinery, seed testing and seed dressing are important methods of achieving better physical qualities, while the development of seed growers' associations and inspection schemes have done much for authenticity and purity. The speaker acknowledged the very valuable part played by the National Institute of Agricultural Botany in this matter of improved seed quality, which has done much to lay proper emphasis on the importance of the highest standards in seed stocks and of the choice of the best varieties.

The sugar beet crop came in for very different treatment from the barley crop, as might be expected from the difference in the agricultural economy, the processing, and the utilization of the two crops. Mr. O. S. Rose, who dealt with the crop in general, speculated on the reasons for the much increased production per acre of sugar beet, and discussed ways in which varieties could be improved to produce what he described as the ideal sugar beet variety of the future. The list of characters was formidable : regularly-shaped single-germ seeds of high germination capacity, easily processed for sowing in a precision drill; strongly growing plants resistant to disease, bolting and chemical sprays ; roots of heavy weight and high sugar percentage with high juice purity; and large tops with neat crowns easily removed by machine. Rose dealt with the practical significance of these characters to the sugar beet and beet sugar industry in Great Britain, making especial reference to the importance of obtaining some control for virus yellows, and he gave warning, from the reported experiences on the Continent, against being optimistic of the benefits of the use of monogerm seed and polyploid varieties. Mr. L. A. Willey elaborated on some of the more important varietal characters already mentioned in describing the results of the N.I.A.B. trials, and made special reference to the importance of bolting resistance (in which the varieties Cambridge K.N.B. and Klein $A A$ are best), and to the difference in the financial returns resulting from growing the best as opposed to the poorest varieties. These two papers emphasized that in sugar beet there is no conflict of interests between grower and processor when it comes to the choice of variety.

The final session of the conference, on the second morning, was devoted to quality in wheat, four papers being given on this topic. Mr. L. Hector Read, in dealing with the economic aspects of wheat quality, referred to the millers' attitude to milling quality, and the quality of the flour in relation to the use to which it is to be put. Read emphasized the vital importance to the miller of these grain characters, and he plesded for a greater understanding by the farmer of the manufacturers' needs when choosing the most suitable varieties to grow, because grain quality is such a strongly expressed varietal character. A similar argument was put forward by Mr. Sebert Humphries, who dealt with flour, bread and biscuits from the millers' point of view. Humphries gave an unequivocal account of the requirements of the miller, the characteristics of foreign and native wheats, and varietal differences on the mill. He asked for there to be a purpose in English wheat production and a due regard for the prestige of English wheats, while he made a strong case for the millers' discrimination in buying particular varieties. Mr. E. N. Greer pressed home the very real differences between wheat varieties in the type of flour they produce, and he also gave an account of tests for milling and baking qualities in the laboratory.

These three papers emphasized strongly the conflict of views between the requirements of the farmer on one hand and those of the processor and manufacturer on the other, except in certain types of wheat. Thus, the most acceptable varieties for the miller, who has to consider the manufacturer who 
will use the flour, are mostly the 'quality' native varieties like Yeoman and Holdfast, while the farmer prefers the higher-yielding, stronger-straw varieties like Cappelle Desprez and Bersee, and the Frenchtype Hybrid 46 bred in Britain. Occasionally the apparently conflicting requirements are reconciled, as in the variety Atle, while, as in barley, hope for further reconciliation was expressed in the characteristics of new hybrids. Mr. D. G. Bullard put the farmers' point of view, and questioned, as did most farmers present, whether the millers would be prepared to pay an adequate premium for grain quality to compensate for the lower yield of the varieties of accepted quality that are available.

As in the case of barley and sugar beet, the wheat problem was left for the plant breeder to resolve as best he can. The conference brought out most clearly the demand and necessity for further improvement in the varieties of the three crops. The scientific problems posed by such continuous improvement are varied, and the work of improving, testing and sifting the plant material is the foundation of a progressive crop husbandry.

The chairman on the first day of the Conference was Mr. Roland Dudley, and on the second day Mr. Samuel Taylor. Dr. G. D. H. Bell summed up the proceedings on both days.

G. D. H. BELI

\section{ANALOGUE AND DIGITAL COMPUTERS}

\section{PROCEEDINGS OF THE WESTERN COMPUTER CONFERENCE}

$\mathrm{T}$ HE proceedings of the 1953 Western Computer Conference, held during February $4-6$ at Los Angeles, California, under the joint sponsorship of the Institution of Radio Engineers, the American Institute of Electrical Engineers and the Association for Compuiting Machinery, has now been published* and contains the full text of the technical papers and of the panel discussion, together with résumés of the four addresses, presented at the Conference. The papers were concerned with the application of computers to the handling of business data and to aircraft design and with recent developments in analogue and digital computing equipment. The subject of the discussion was "An Evaluation of Analog and Digital Computers", and the panel of four experts, under the chairmanship of Prof. G. D. McCann, of the California Institute of Technology, consisted of Dr. J. L. Barnes, a mathematician and engineer, Mr. F. Steele, vice-president of Digital Control Systems and an engineer, Dr. L. Ridenour, formerly a nuclear physicist and now vice-president of the International Telemeter Corporation, and Dr. A. W. Vance, an electronics engineer of the Radio Corporation of America.

The addresses were delivered by Dr. Simon Ramo, of the Hughes Aircraft Company, Dr. R. D. Huntoon, of the National Bureau of Standards, Dr. Lee A. DuBridge, president of the California Institute of Technology, and Dr. J. E. Hobson, director of the Stanford Research Institute. Dr. Ramo dealt with the impact of computer development on the training * Proceedings of the Western Computer Conference held by the
Joint IRE-AIEE-ACM Computer Conference Committee California, February 4-6, 1953. Pp. 231. (New York: Institute of Radio Engineers, Inc., 1953.) 3.50 dollars. and utilization of engineers. He maintained that the development of computers is work which may soon be engaging the greatest number of engineers and scientists ; specially trained graduates with a knowledge of the physical sciences (with emphasis on electronies), the workings of the human brain and business and industrial procedures in addition to government and labour regulations are required, and industry must particularly avoid large programmes until such capable technical experts are available. Dr. Huntoon discussed the factors influencing the effective use of computers and coined the word "psycho-numerosis" to describe the problem of matching computing machines to the needs of research workers. He suggested that "electronic brains", like human brains, in the process of evolution must adapt themselves to their environment in order to survive and prosper.

The complex problem of scientific man-power was the subject of Dr. DuBridge's address. He outlined the salient factors which affect the supply and demand of scientists and engineers and suggested measures to remedy the present inadequate supply. Finally, Dr. Hobson, in an address entitled "New Equations for Management", reviewed the various new factors which the complexity of industrial operations have introduced and indicated how the facts produced by applied research may be properly presented to and utilized by the managements of industrial concerns.

The eighteen technical papers were presented in four sessions. The first and second sessions were devoted to applications of computers to commercial and to aircraft design problems, respectively. The third and fourth sessions dealt with more specific technical problems in the design and use of particular sections or types of computers and included papers on the 'Nordsieck' computer; the new laboratory for three-dimensional guided missile simulation devised by the Reeves Instrument Corporation, New York; an improved cathode-ray tube storagesystem; ferroelectrics as a memory element for digital computers; and the solution of partial differential equations by difference methods using the electronic differential analyser.

\section{METEOROLOGICAL OFFICE}

\section{ANNUAL REPORT FOR 1952-53}

$T$ HE Meteorological Office has the task of meeting the civil and Service (except naval) requirements of Great Britain for meteorological information of all kinds and of improving by research its ability to meets those needs. A feature of the report of its work during the year April 1, 1952-March 31, 1953*, is that during this period the organization for the provision of weather forecasts and other information was extended. One example of this was the application to the east coast as a whole after January 31 , 1953, of the system of special warnings of meteorological situations known to be associated with coastal flooding, which had been applied successfully to the River Thames in London for many years. Experiments in the transmission by facsimile equipment to selected out-stations of charts drawn at the Central Forecast Office were begun with the view of im-

- Annual Report of the Director of the Meteorological Office for the Year April 1, 1952, to March 31, 1953. (M.O. 573.) Pp. 56. (London: H.M.S.O., 1953.) 28. net. 